\title{
Idiopathic proliferative verrucous leukoplakia: report of a clinical rarity
}

\author{
Anand Pratap Singh, ${ }^{1}$ T R Chaitra, ${ }^{2}$ Adwait Uday Kulkarni, ${ }^{3}$ Prasad N Jathar ${ }^{4}$ \\ 'Department of Oral Medicine and Radiology, Rungta College of Dental Sciences, Bhilai, Chhattisgarh, India \\ ${ }^{2}$ Department of Pedodontics, Kothiwal Dental College and Research Centre, Moradabad, Uttar Pradesh, India \\ ${ }^{3}$ Department of Oral and Maxillofacial Surgery, Sinhgad Dental College and Hospital, Pune, Maharashtra, India \\ ${ }^{4}$ Department of Pediatric Dentistry, Sinhgad Dental College and Hospital, Pune, Maharashtra, India
}

Correspondence to Dr Adwait Uday Kulkarni, dradwaitkulkarni@gmail.com

\section{DESCRIPTION}

Proliferative verrucous leukoplakia (PVL) is a rare and specific disease that differs from oral leukoplakia, which is neither a delimited lesion nor a condition. ${ }^{1}$

A 56-year-old, healthy steel plant male worker reported with a chief complaint of painless white patches on the right buccal mucosa and burning sensation in the same region since 1 year.

History and general physical examination revealed no relevant findings and also no tobacco-chewing habit was evident, except for using herbal tooth powder. On examination, a white lesion with multiple peaks on its surface was seen on the right buccal mucosa and vestibule, which were coarse, tough, non-scrapable and non-tender on palpation (figure 1). The surrounding mucosa was normal in structure and colour.

Routine haematological investigation, PCR test for human papilloma virus (HPV) and incisional biopsy were performed.

Haematological investigation values were found within normal limits while HPV was not detected by PCR.

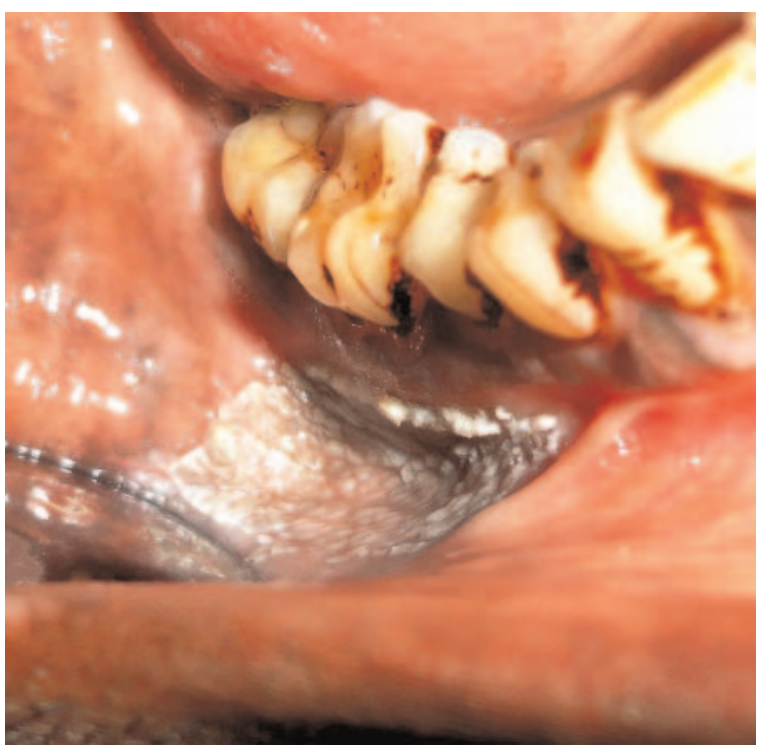

Figure 1 Photograph showing the lesion.
The H\&E-stained sections revealed proliferative corrugated hyperkeratosis, acanthosis, increased mitoses, broad rete ridges and inflammatory cell infiltrated connective tissue stroma (figures 2 and 3 ) which indicated a diagnosis of PVL with mild dysplasia.

Histopathological continuum encompasses four stagesplaque of hyperkeratosis without dysplasia, verrucous hyperplasia, verrucous carcinoma and finally oral squamous cell carcinoma.

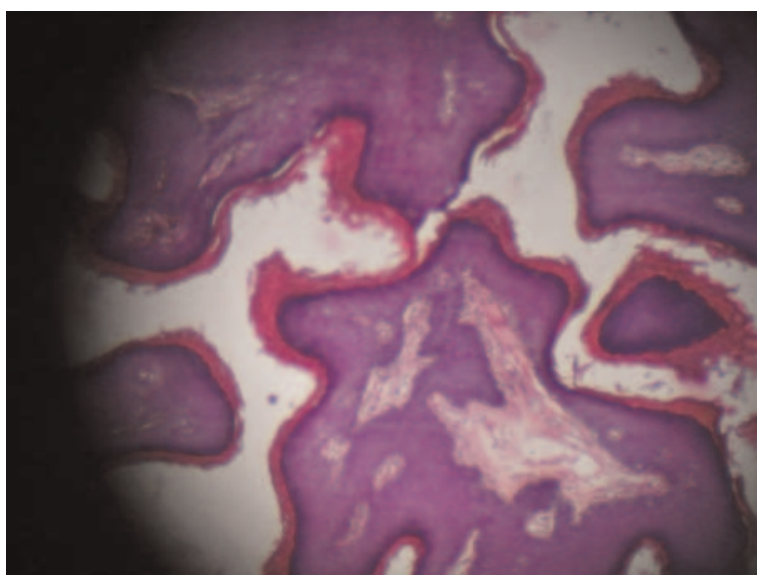

Figure 2 H\&E-stained section.

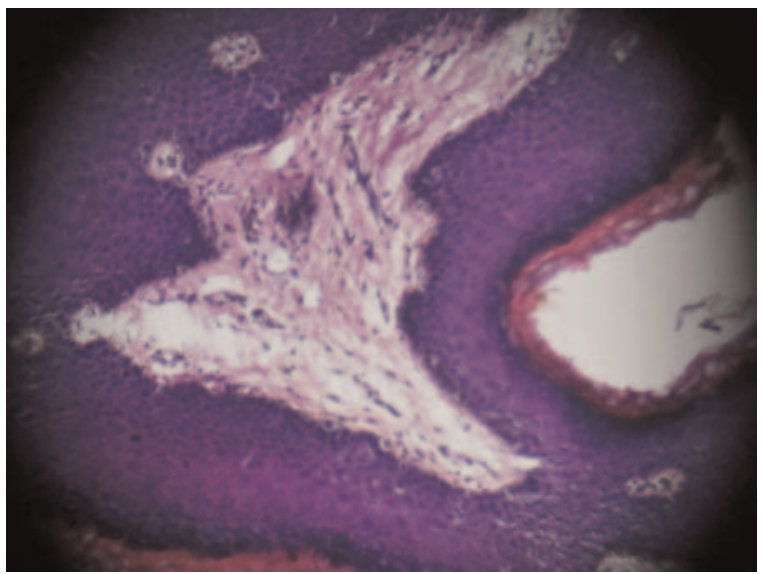

Figure 3 Magnified H\&E-stained section. 


\section{BMJ Case Reports}

PVL is often seen in middle-aged women ${ }^{2}$ and the female-to-male ratio is roughly $4: 1$. PVL is not strongly associated with alcohol or tobacco use, but the possible aetiology includes HPV, Epstein-Barr virus and immunity. ${ }^{2}$ PVL initially presented as a solitary flat homogenous leukoplakia, while others present with multiple involved sites. The recurrence after treatment is commonly seen. Differential diagnosis includes frictional keratosis, homogenous leukoplakia, papilloma and verrucous carcinoma.

Treatment recommendation includes multiple techniques such as $\mathrm{CO}_{2}$ laser surgery, surgery with radiotherapy, cryotherapy, retinoid, systemic vitamin A, bleomycin and photodynamic therapy. ${ }^{3}$ Our patient is under follow-up to observe the prognosis of the treatment and to monitor the histopathological changes, as the lesion has a high potency to turn into carcinoma.
Competing interests None.

Patient consent Obtained.

\section{REFERENCES}

1. Silverman S, Gorsky M. Proliferative verrucous leukoplakia: a follow-up study of 54 cases. Oral Surg Oral Med Oral Pathol Oral Radiol Endod 1997;84:154-7.

2. Ge L, Wu Y, Wu LY, et al. Case report of rapidly progressive proliferative verrucous leukoplakia and a proposal for aetiology in mainland China. World $J$ Surg Oncol 2011;:9:26.

3. Poveda-Roda R, Bagán JV, Jiménez-Soriano Y, et al. Retinoids and proliferative verrucous leukoplakia (PVL). A preliminary study. Med Oral Patol Oral Cir Bucal 2010;15:e3-9.

\section{Learning points}

- The purpose of this article is to inform the dentist that histopathological examination is mandatory along with that, assessment of immune status and viral infection status, for diagnosis of proliferative verrucous leukoplakia.

- Regular follow-up should be done to monitor the histopathological changes, as the lesion has a high potency to turn into carcinoma.

This pdf has been created automatically from the final edited text and images.

Copyright 2012 BMJ Publishing Group. All rights reserved. For permission to reuse any of this content visit http://group.bmj.com/group/rights-licensing/permissions.

BMJ Case Report Fellows may re-use this article for personal use and teaching without any further permission.

Please cite this article as follows (you will need to access the article online to obtain the date of publication).

Singh AP, Chaitra TR, Kulkarni AU, Jathar PN. Idiopathic proliferative verrucous leukoplakia: report of a clinical rarity. BMJ Case Reports 2012;10.1136/bcr-2012-006194, Published XXX

Become a Fellow of BMJ Case Reports today and you can:

- Submit as many cases as you like

- Enjoy fast sympathetic peer review and rapid publication of accepted articles

- Access all the published articles

- Re-use any of the published material for personal use and teaching without further permission

For information on Institutional Fellowships contact consortiasales@bmjgroup.com

Visit casereports.bmj.com for more articles like this and to become a Fellow 